\title{
INTEGRATING TUBB'S ENGAGEMENT MODEL WITH CRITICAL
READING
}

\author{
Irma Wahyuny \\ Ibrahim $^{1+}$ \\ Noor Hanim \\ Rahmat $^{2}$ \\ (iD) Nor Syahiza \\ Shahabani $^{3}$ \\ Sharifah Nadia \\ Syed Nasharudin ${ }^{4}$ \\ Izlin Mohamad \\ Ghazali $^{5}$ \\ Zulaikha \\ Khairuddin $^{6}$
}

\section{Article History}

Received: 28 June 2021 Revised: 2 August 2021

Accepted: 6 September 2021

Published: 29 September 2021

\section{Keywords}

Critical reading

Group engagement

Orientation

Conflict

Consensus

Closure.

\author{
${ }^{1, s, 4,5,6, A}$ Akademi Pengajian Bahasa (English Department) Universiti Teknologi \\ MARA Shah Alam, Malaysia. \\ 'Email:irma.wxy@gmail.com Tel:016-2357323 \\ ${ }^{3}$ Email:norsya1974@gmail.com Tel:017-2706889 \\ Email:sharifahnadia@uitm.edu.my Tel:012-5765853 \\ ${ }^{5}$ Email: izlin449@uitm.edu.my Tel:017-3208780 \\ ${ }^{6}$ Email: zulaikha5497@uitm.edu.my Tel:012-9564817 \\ 'Akademi Pengajian Bahasa (English Department) Universiti Teknologi \\ MARA Cawangan Johor Kampus Pasir Gudang, Malaysia. \\ ${ }^{2}$ Email:noorh763@uitm.edu.my Tel:016-2155797
}

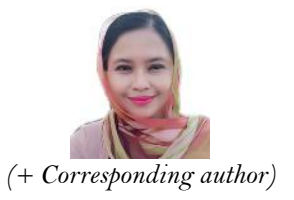

(+ Corresponding author)

\begin{abstract}
Since critical reading has been assumed as critical, there are actually certain ideas and concepts that reflect how critical is this critical reading. Critical does not mean critical as in difficulty or failure in reading but more of looking into the skills, processes and the activities when reading. Group engagement has been said to improve team members' critical thinking skills. This study is done to explore how group interactions facilitate critical reading activities. Specifically, this study explores how group work encourages critical reading through the processes of orientation, conflict, consensus, and closure. 72 participants responded to the instrument (a questionnaire). The questionnaire has 5 sections, demographic profile, orientation, conflict, consensus and also closure. Data is analyzed using SPSS version 26 to reveal percentage for the demographic profile and mean score for the variables. Findings indicate that group engagement facilitates critical reading in several ways. The study suggests that communication during group interaction improves learners' critical reading.
\end{abstract}

Contribution/ Originality: This study is one of the few studies that integrates Tubb's engagement model with the learning of critical reading among ESL learners. The model is used to describe the group engagement among learners and this interaction promotes critical thinking skills.

\section{INTRODUCTION}

\subsection{Background of Study}

Critical reading demands extensive and interactive higher order thinking skills, which includes understanding the ideas, brainstorming and arranging points, providing salient supports to defend own perspectives, comparing arguments, making inferences and organizing perspectives either inductive or inductively in order to generate unbiased or objective judgements (Browne \& Keeley, 2007; Koray \& Çetinkılıç, 2020). Critical reading skill is a crucial skill to be taught in secondary and tertiary education, as it prepares the learners to become critical and comfortable gauging materials in their university classrooms and become successful learners (Howard, Gorzycki, 
Desa, \& Allen, 2018). The skill also benefits them when they can utilize the skill personally and professionally as the member of community.

Critical reading has vast differences than reading. Mullis, Martin, Foy, and Hooper (2017) presented in TIMSS \& PIRLS International Study Centre website from Boston college that reading is when the readers have the ability to comprehend, construct meaning from texts in a variety of forms and finally express their understanding in written and verbal forms. Reading only involves the first three levels of Blooms taxonomy, which are knowledge, comprehension and application, whereas Critical reading focusses on the higher levels of learning, specifically called as Analysis, Synthesis and Evaluation (Blooms, 1956).

According to numerous researches based on theory of the sociocultural theory by Vygotsky (1978) and the social cognitive theory by Bandura (1977) learners learn better when group interaction occurs (Stajkovic \& Sergent, 2019). Vygotsky (1978) presented that learning will develop in group interactions when learners will grasp, regulate and control their own cognitive process in communicative activities. During group interactions, exchanging ideas and thoughts are presented between the cognitive minds and language works as the principal component that helps reshape the knowledge.

\subsection{Statement of Problem}

Learning can be less taxing than acquiring, that learners (when acquiring) have to apply the skills in and out of classroom - for instance, in the language acquisition; as what Krashen said, the content in the messages conveyed is important. Unlike learning - where learners are to pick up rules and skills that are taught to them; then the most important is to grab the understanding. Some said acquiring (acquiring language, for instance) is more to informal routine while learning involves formal setting (Jayendran, Ramanathan, \& Nagpal, 2021; Krish, Hussin, \& Sivapuniam, 2011) that learners have to go through certain stages of classroom teaching and learning process. However, both learning and acquiring have to be made easy so that learners will find these two convenient to be adapted. Amritesh and Jeayaram (2019) found out from their study that if learning materials, approaches and techniques are made easy, learner's learning can be at ease and improved. Hence, Connectionism theory by Thorndike (2017) introduced the law of learning that learners are to be motivated to learn when there are many practices offered and later reward can be obtained. Therefore, for learners to learn critical academic reading and later acquire the skills can be determined by how the lessons are conducted and how the lessons are planned to be transferred (Javadi \& Tahmasbi, 2020).

Since critical reading has been assumed as critical, there are actually certain ideas and concepts that reflect how critical is this critical reading. Critical does not mean critical as in difficulty or failure in reading but more of looking into the skills, processes and the activities when reading. It is more of getting the readers to know what should be done when reading (the process); what a proper and suggested method to adapt when reading (the model); what would be the concepts, the beliefs, or perhaps the principles of reading (the theories); and what actually, in reality, questions to be asked during the reading. All these can act to assist readers to accomplish better understanding and to reduce stress when reading. With the proper guidance (Barashid, 2020) and systematic approach on reading adapted, readers will find critical reading as easy and fun - that later can enrich their reading ability and potential.

Critical reading can be as smooth as other leisure and relaxing reading activities when it is done right - that however, cognitive process is needed and involved. Piaget's theory on cognitive development does mention about how one is able to interpret idea based on the stimulus, and later the thinking moves to find the relationship between the idea and other related factors such as current environment or the past events (Piaget, 2001). Diaz (2018) and Malakowsky (2018) encouraged for reading more texts to ensure the liking and the understanding of what learners read - the more the learners read, the more they see connections of the content in which the metacognition process begins. This process is critical but beneficial as it is to ensure reading success (De Souza, 
2017). The cognitive process; in order to determine the successful result of the idea interpretation as mentioned earlier, however, depends on an individual's age. Thus, for the learning purposes, any learning materials and methods or any given reading materials have to suit the person's or the learner's age level (Egan, 2014). For instance, phonic reading method is now being emphasized in some kindergartens in Malaysia as it is found effective for children age three to nine. Somehow, at the varsity level, reading critically matches the learners' ability and it is beneficial for their learning journey. In Malaysia, all the skills are exposed to students - where they are to enroll for critical reading skills class in a particular semester. Learners are required to not only grasp the general idea and the supporting details of the reading text but also all the skills behind and beyond the reading; for instance, to distinguish facts and opinion, to make inferences and draw conclusions, to differentiate inductive-deductive reasonings skills, and so forth. It does not stop there; they also have to be able to examine author's bias and to evaluate author's arguments (De Souza, 2017; Larking, 2017). That is challenging indeed.

To complement the challenges, many scholars have introduced varied methods of critical reading to ensure successful reading - at any age level. To that, the instructors have to be sensitive of their learners' learning variation that they need to come out with suitable reading methods to assist these learners (Egan, 2014). One of the successful methods is Graphic Organizers (GO) where readers read via "visual representations of knowledge that structure information by arranging important aspects of a topic into patterns using labels" (Barashid, 2020). It is said that GO helps learners to relate what they read to their schemata, and later (with this previous knowledge that they have) they will make some sense of the current reading content (Carillo, 2017). The researcher affirmed that this reading method is effective and encouraged language readers to apply GO.

Furthermore, though critical reading $(\mathrm{CR})$ is hard to master, every now and then, learners are offered varieties of reading methods, approaches, techniques and strategies. After all, it depends on each individual how to go about managing their reading. Learners or readers, specifically, can adopt any techniques too (skimming, scanning, or perhaps for more advanced activities - questioning during reading, mind-mapping, making notes, and so forth) that help ease reading. Additionally, being active and critical (by adapting a metacognitive process) during reading are excellent. These activities do reflect one's outstanding reading ability or it can be said one's absolute reading talent that very much beneficial. However, to be active readers is the most challenging in reading activity because to acquire the skills for critical reading or "evaluative comprehension" skill are the highest level of reading skills (De Souza, 2017). Thus, in order to accomplish "productive" reading, a reader should have some alertness then when reading - that to ensure they are jotting down points and then reflection is to be made. That is being 'critical'. However, the question to ponder; do all of us have this ability? Many can tell that reading can be easy if "I know the subject area" or it does not make any sense when "I don't understand. This is beyond my area of study". This is true indeed. Nevertheless, if it is guided right and being mentored appropriately, reading can be easy and the understanding can be obtained effortlessly. Based on the findings by Wilson (2016) learning English (the EAP learners) requires a "positive, fun, creative and supportive classroom" so that learners are able to interact and speak up amongst themselves. Reading and learning together in groups is very much advisable (Wilson, 2016) to ensure reading efficiency.

With all many studies conducted, it has been discussed and debated whether critical reading affecting learning, and to that - numerous findings shared that reading is one great potential to learning success. Failing to acquire the skills can result in several alarming issues - it possibly affects the learners emotionally, and later can affect them academically and socially. For instance, in educational setting, most academic matters are to be coped with reading, thus, reading becomes an essential tool for learners - it is either they are at the school level or the varsity level. In some cases, learners are potentially to face learning anxiety and low self-esteem when reading becomes their ultimate problem. At varsity level for example, learners have to equip themselves with good critical reading skills (Wilson, 2016). They are not just reading for content in general but the reading has to be more than that when it is required of them to summarize, to analyze, to synthesize (Sand, 2016) and so forth. All these mentioned reading 
requirements and abilities enable them to successfully complete any given assessments; and also, it is in fact the fundamental skill of their whole learning program. To that, the learners will be able to think critically too, in which it is a skill, very much needed when one at the varsity stage (Larking, 2017). Hence, it is long known that learners' anxiety then can be triggered due to not being able to cope with the completion of assignments and other university related assessments (Karanja, 2015). On the other hand, in relation to that, the occurrence of low self-esteem happens when their peers are doing better in the academic field as compared to what they manage to achieve.

In addition, having knowledge on the critical reading skills are deemed an excellent advantage. This extra learning value in them (to be able to read for content along with questioning, analyzing and synthesizing text) helps them to comprehend the content faster and more accurately. Carillo (2017) encouraged learners to be able to ask question during reading - that this drive makes reading understandable. However, without all these great reading potentials, learners will have hard time in their study - to face the reality of their downside of academic achievement, as well as to face their peers who are of better achiever. For instance, Diaz (2018) also mentioned that having the ability in reading helps in other related language skills too like grammar. This shows the needs to be good at reading skills - not for content comprehension alone but to support other learnt skills too (Sand, 2016). Hence, with the discouraging realities of reading failure mentioned earlier do give impact to the learners emotionally, academically and socially.

Hence, this study is done to explore how group interactions facilitate critical reading activities.-Specifically, this study is done to answer the following questions

- How is Orientation portrayed in critical reading activities?

- How do learners deal with Conflict during critical reading activities?

- How do learners arrive at the Consensus during critical reading activities?

- How is Closure done during critical reading activities?

\section{LITERATURE REVIEW}

\subsection{Critical Reading Strategies}

Critical reading can be perceived as a creative process in which readers bridge their outside knowledge with the text and the writers by reading behind the lines. Yu (2015) agrees that critical reading is an analytic activity which involves a lot of thinking and analyzing. According to Larking (2017) for critical readers to comprehensively grasp the full meaning of a text, it is their task to 'read between the lines' and undertake an analysis of at text. To achieve this, previous researchers have suggested numerous types of critical reading strategies based on pre-reading, whilereading and post-reading activities. (Salisbury University, 2013 as cited in Begunova (2018)) suggested seven critical reading strategies namely previewing, contextualizing, questioning, reflecting on challenges to your beliefs and values, outlining and summarizing, evaluating, and comparing and contrasting. We could describe these seven strategies in the Figure 1 (adapted from Begunova (2018)).

In line with this, Yu (2015) also suggested five critical reading strategies that are frequently used in language classroom which are (i) pre-reading, (ii) reading in context, (iii) further the understanding by asking questions and answering them, (iv) further thinking and reflections after reading and (v) outlining and summarizing which lead to a better comprehension. To sum up, from educational perspective, these critical reading strategies are very crucial for readers not just to comprehend the text but also to critically analyze and synthesize what is read to become better readers.

\subsection{Group Interaction}

Social interaction during class activities can benefit students in more than just facilitating the understanding of content. Group work for instance helps student to improve thinking capacity. According to Vygotsky (1987) this type of social interaction involving cooperative or collaborative dialogue promotes cognitive development. 
Vygotsky's social interaction is based two main principles; (a) the More Knowledgeable Other (MKO) and (b) the Zone of Proximal Development (ZPD). The group interaction allows team members to learn for their "more knowledgeable other" in the interaction. They may come to understand ideas better when it is explained by their peers instead of the person in authority (their teacher). In addition to that, the knowledge gained as a team is more than the knowledge that the students gained when they are alone. The difference between what the learners gained as a group minus what they gained alone is thus called the zone of proximal development. So, group interactions benefit the learners in many ways.

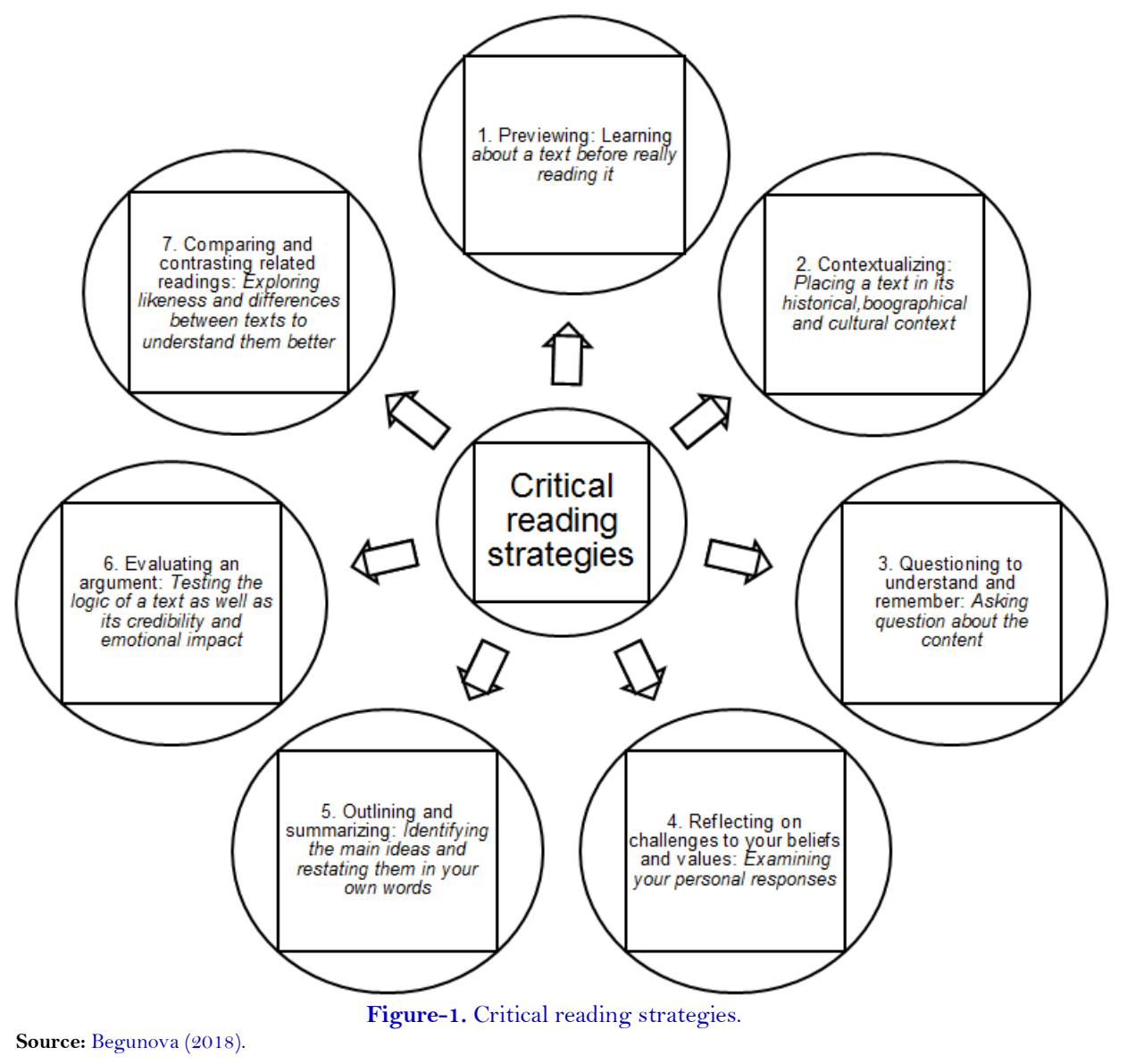

Besides, when the students work in small groups, they will be able to produce more thoughtful outcomes and solutions. They could gain this from the social interaction that takes places among the team members. Borůvková and Emanovský (2016) highlighted that when the students work in small groups, they will be exposed to various solving strategies as the students are pointed to various point of views. This will create a good opportunity for them to evaluate the suggestions critically and renew their views on the possible solutions. Furthermore, Borůvková and Emanovský (2016) added that this is valuable for complex problems that cannot be solved by routines or algorithms. However, they also emphasized on the need for the group members to agree on a common solution for this to work. Thus, with mutual consensus, working is small groups enable the students to creatively solve problems.

In addition, the other benefit of working in group work is the students will learn to become team players. In his study, Rezaei (2018) found that group work is used to improve the students' teamwork skills. This is based on the opportunity created to get the students to cooperate in completing tasks given. Usually, the group will be led by an appointed team leader as they learn to segregate smaller parts for each member to deliver. The process will encourage them to work together in achieving a similar goal. It will also train them to be accountable of the 
individual parts assigned given to them. Nevertheless, Rezaei (2018) pointed out that even if the students view this as a beneficial to them, they prefer to be evaluated individually for their respective contributions. Hence, this shows that the students view group work as an opportunity to perform as a good team player.

These benefits can be obtained if the right sets of strategies are used to guide the students when working in small groups. Burke (2011) suggested for the instructors to focus on the beginning of the group work. This includes the early stages of forming the group, assisting to negotiate the group process and deciding the form of evaluation for the final product. When these are established carefully, the students will be in the right group size for the volume of work they are assigned to do. Additionally, Rezaei (2018) also listed the group work strategies suggested in the literature which consist of explaining to students on how will the group function and the evaluation in order to set their expectations earlier. He also put in the necessary ground rules for the students to avoid academic misconduct, such as cheating and plagiarism. In short, underlining the basics will ensure that the students will be able to experience the benefits of group work.

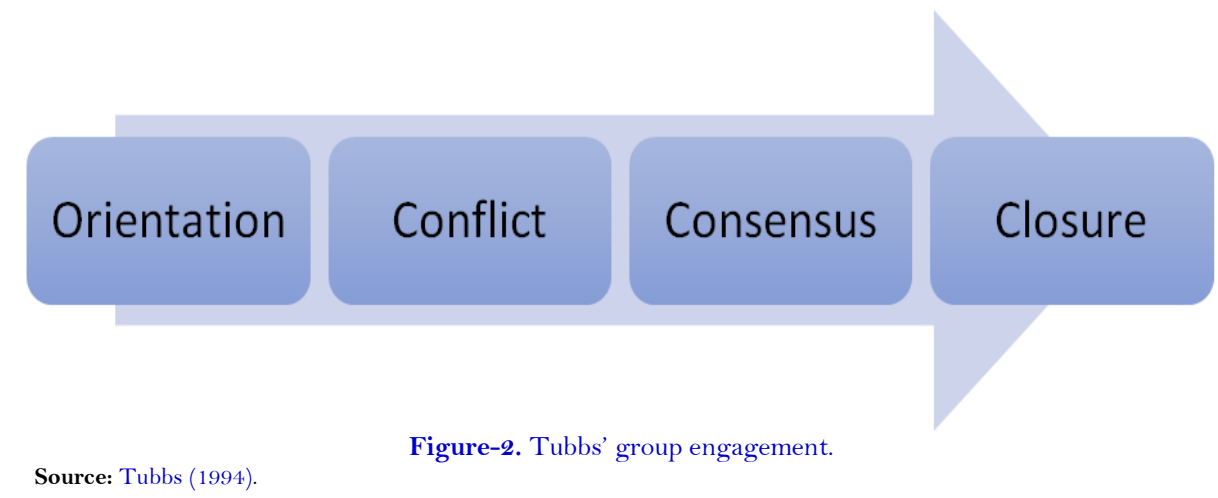

\subsection{Tubb's Group Engagement}

\subsubsection{Four stages of Tubb's Theory}

The first stage of the theory is (a) Orientation. With reference to Figure 2, the getting-to-know team member's stage. The members share their problems and will prepare the restrictions and opportunities assumed to confront the problem. The second stage (b) Conflict, at this stage the problem is analyzed and each individual tries to convey get into a solution through their perspective. The third stage is (c) Consensus. Out of the many solutions by each individual, as a group they will reach to an agreement and will select the best feasible answer to the problem. The last stage is (c) Closure. In the final stage, the announcement of the decision taken by the people. The final solution is confirmed by the people to support their ultimate decision.

\subsection{Past Studies}

\subsubsection{Studies in Group Interaction in the Classroom}

Collaborative learning could help students to interact and learn the language in non-threatening environment. According to research done by Situmorang (2021) she would like to examine the students' perceptions on using Group Work as one of the methods in teaching English language. There were 50 samples purposively chosen for the study and they were eleventh and tenth graders. The researcher utilized questionnaire in obtaining the data and based on the result, it was discovered that the students perceived that the group work was advantageous in learning and majority of them had positive attitudes towards learning in group as they could solve their problems collaboratively. The implications of the research are, the students could be more confident, be respectful towards one another and they could learn on how to be a responsible person.

Interaction in classroom could be one of the factors to scaffold students to learn English language. Sundari (2017) investigated on the interaction among students in classroom in learning foreign language. There were two 
focused-group, and the samples were lower secondary school students, and the data were obtained from 12 semiinterview sessions and 13 classroom observations. The findings of this research there were a few factors that affected interaction in the classroom which were practices, teachers, students, learning objectives and class context. Since, this research came out with a model of classroom interaction, the policy makers and schools need to take into consideration to embed this model in the school curriculum as it will benefit both teachers and students.

Studies on the zone of proximal development also proved the efficiency of group interaction in classroom. The term "zone of proximal development" refers to a concept introduced by Vygotsky (1978) means the difference between what a learner can do without help and what a learner can do with guidance (peers and parents) and educational support (teachers). Vilches (2020) has conducted a study to improve social assimilation among nonEnglish language learners and English language learners. The study was designed to 538 high school students at Westlake High School in the Mount Pleasant Central School District in New York. In her study, Vilches (2020) strongly believed that The Zone of Proximal Development clearly provided the potential that their students can produce to show their intellectual, linguistic, and creative strengths in the classrooms. Teachers also provided students suitable learning experiences and support to help them realize their potential development. Vilches (2020) developed several instruments to promote group interaction in classroom, which include improved lesson plans, professional development plan and monthly in-house faculty professional development. The findings of this study revealed improvements levels of speaking, listening, comprehension and social integration of the learners with their peers. Consequently, this study can be used by other educators to improve larger-scale learning institutions.

\subsubsection{Studies on Critical Reading}

There are numerous studies conducted on reading; and the results revealed so many positive impacts on successful critical reading (CR). CR is normally carried out in a classroom setting that guides learners (L1 or L2) on how to manage their comprehension through effective and critical techniques. CR is a concept of reading in depth; or reading beyond the general content of text. It is getting into the author's thoughts - seeking how the author thinks, what is the text tone, why the author writes, and so forth. In addition, reading or specifically CR offers learners varied methods to read effectively as to accommodate the ease of reading (Pradnyadewi \& Kristiani, 2021). One of the relevant critical reading (CR) activities is to be carried out in a group - where learners get to interact amongst their group members (Wilson, 2016). It is also called a Collaborative Reading (Pearson, Owen, Thimbleby, \& Buchanan, 2012). The group interaction is observed as a positive move in a reading class (Pearson et al., 2012) because the learners are able to ask question, to share their emotion if they face reading difficulty, to explore other people's understanding on the content, to seek for any suitable reading techniques that their team members applied, and many other benefits. Furthermore, speaking of interaction activities during the CR, it can be conducted through the classroom conventional approach or via computer-based technology (CR in a digital mode). Koçak (2018) has carried out this group reading activity for the purpose to look up for effective reading techniques to help their students wanting to read and to make reading as active and creative to the students - which they can finally shape their life ahead. This study is conducted (conventionally) to a group of secondary school (high school) students - targeting the 9th, 10th and 11th grade students. It is called a "Reading Group Activity". The participants of the study were grouped together, and six to seven members were allocated per group. It allows the readers to cooperate amongst their small group members to support each other's understanding, enrich their reading skills, share feedbacks of the content read (to provide and to receive) and so forth. This effort is meaningful and much appreciated (if carried out) to the learners who are not well versed of their reading. It is found (from the study) that this critical reading method helps to boost learners' interest in reading and improve their critical reading skills; as well as increase their ability to "make reading preferences and to distinguish qualified works" (Koçak, 2018). 
On the other hand, Pearson et al. (2012) had also carried out this group reading activity but it was conducted digitally. It was conducted to compare and to find answer if reading group activity via the iPads (Buddy Books) is more effective than the one using physical books and papers. "18 participants $(1 \mathrm{oF}, 8 \mathrm{M})$ aged between 22 and 61 to take part in the study”. The results again revealed that CR through group interaction is encouraging, and this study too proves that the digitally group reading interaction is a better preference in comparison to the conventional CR group approach. The researchers of this study permitted for others to run the same research to obtain more exclusive data and new findings as "different styles and contexts of collaborative reading" can be explored (Pearson et al., 2012).

Regardless of the number of critical reading strategies used by readers, it is proved that the strategies help to enhance reading comprehension and writing performance, as well as improving students' vocabulary. A study conducted by Suacillo, Um, Velasquez, Villaflores, and Cequena (2016) found that there is a constructive correlation among critical reading strategies, reading comprehension and analytical writing performance. The correlational study was done with 45 ESL students from University of Santo Thomas, Philippines using reading comprehension test, analytical writing test and questionnaires. The findings of the study revealed that reflecting and contextualizing were the two strategies frequently used by the respondents. It is also proved that there is a positive effect of critical reading strategies to students' reading comprehension and writing performance hence providing a clearer direction on how educators can help learners learn better through the application of critical reading strategies in classroom. In another study done by Khabiri and Pakzad (2012) it is found that critical reading strategies helped to increase students' vocabulary retention. $72 \mathrm{EFL}$ students ranging from low to high intermediate level of English language proficiency who participated in this experimental study were given a vocabulary pre and post-test as well as 19 treatment sessions. The experimental group was taught using critical reading strategies while a common comprehension-based approach was applied with the control group. In conclusion, it was agreed that the positive influence of critical reading strategies on reading comprehension also contributed to vocabulary retention indirectly. Therefore, the findings of this study can be used by language teachers to create an awareness of these critical reading strategies for students to improve their language learning skills such as reading, writing and vocabulary.

\subsection{Conceptual Framework}

This study Figure 3 is rooted from the theories of (a) Group Engagement by Tubbs (1994) and Critical Ready Skills (Sultan \& Nurhadi, 2017).

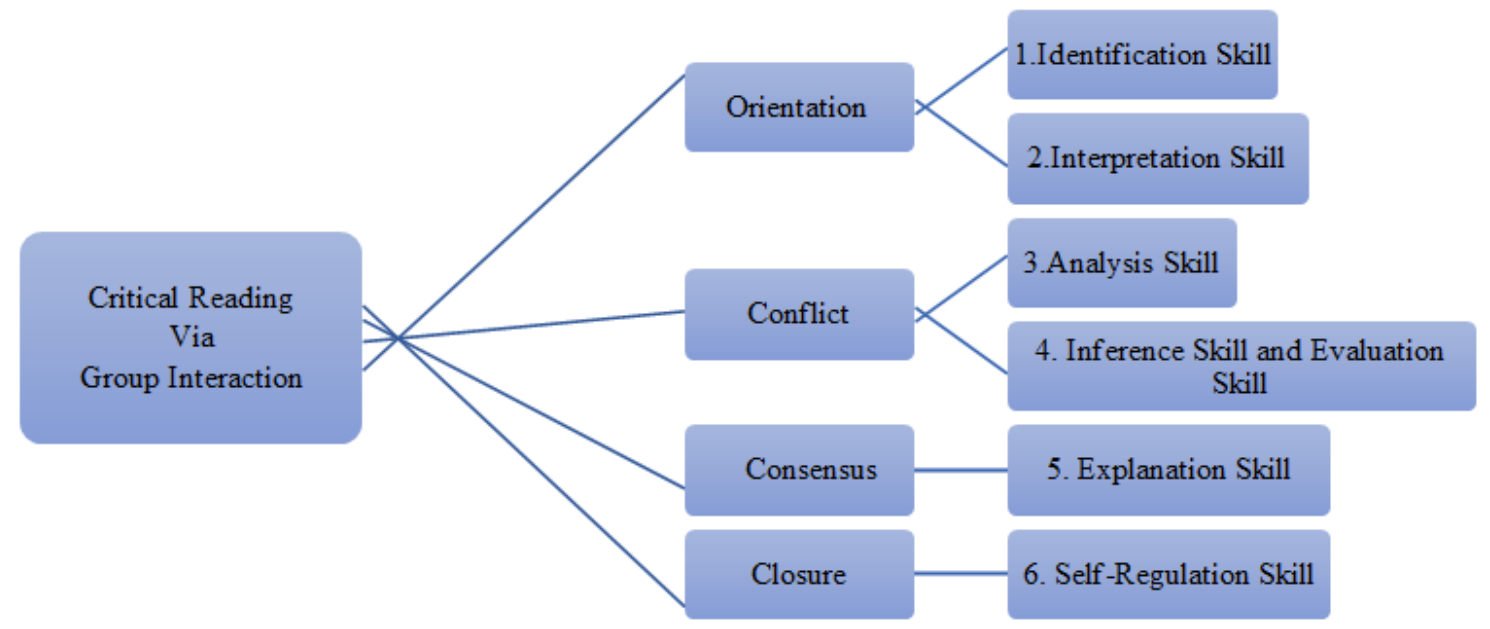

Figure-3. Conceptual framework of the study. 
Group engagement (Figure 3) is one way to facilitate critical reading among learners. Tubbs (1994) believes that in any group interaction, learners go through four stages. The stages are (a) orientation, (b) conflict, (c) consensus, and (d) closure. Firstly, the (a) orientation is the initial stage where learners work as a team to (1) identify and (2) interpret skills. Initial discussion (especially among newly formed team members) may face (b) conflicts. The conflicts actually pave way for the use of (3) analysis and also (4) inference and evaluation skills. Next, in order for the group to arrive at the (c) consensus, the members (especially the group leader) need to summarize the ideas using (5) explanation skills. Finally, the (d) closure is done as the group makes reflections that can act as (6) self-regulation.

\section{METHODOLOGY}

This study in a form of survey was administered to 72 students from four different classes from a public university in Malaysia. The quantitative data have been collected at the end of the research. The questionnaire (refer to Table 1) consists of 5 sections; first section explains participant's demographic profile, second section focusses on Orientation and attempts to identify Team Engagement, Identification skills and Interpretation skills; third section concentrates on Conflict and seeks to explain Conflict, Analysis skill and Inference and also Evaluation Skill; fourth section emphasizes on Consensus and strives to clarify Consensus, Explanation Skill and the final section centers on Closure and aims to describe Closure and Self Regulations Skills. Five-point Likert scale: 5 for "strongly agree", 4 for "agree", 3 for "undecided", 2 for "disagree" and 1 for "strongly disagree" is used for the survey. Data is analyzed using SPSS version 26. Cronbach analysis was carried out on the instrument to reveal $\alpha=$ .946 thus showing high internal reliability refer to Table 2.

Table-1. Distribution of items in instrument

\begin{tabular}{l|l|l|l}
\hline Section & Main Idea & Sub-Idea & No Items \\
\hline \multirow{2}{*}{$\mathrm{B}$} & ORIENTATION & Team engagement & 5 \\
\cline { 3 - 4 } & & Identification skills & 7 \\
\cline { 3 - 4 } & & Interpretation skills & 5 \\
\hline $\mathrm{C}$ & CONFLICT & Conflict & 5 \\
\cline { 3 - 4 } & & Analysis skill & 5 \\
\cline { 3 - 4 } & & Inference \& Evaluation Skill & 5 \\
\hline $\mathrm{D}$ & CONSENSUS & Consensus & 5 \\
\cline { 3 - 4 } & & Explanation Skill & 5 \\
\hline $\mathrm{E}$ & CLOSURE & Closure & 5 \\
\cline { 3 - 4 } & & Self-Regulations Skills & 5 \\
\hline
\end{tabular}

Table-2. Reliability statistics.

\begin{tabular}{c|c}
\hline \multicolumn{2}{c}{ Reliability Statistics } \\
\hline Cronbach's Alpha & N of Items \\
\hline 0.946 & 52 \\
\hline
\end{tabular}

\section{FINDINGS}

\subsection{Findings for Demographic Profile}

This section presents the demographic data and data analysis of the finding based on the four research questions.

This study involved 72 respondents. Figure 4 shows the demographic data of respondents who participated in the study with most respondents $(79 \%)$ being female and the remaining $21 \%$ being male. The percentage shows that the female respondents are higher than male respondents. 
Gender

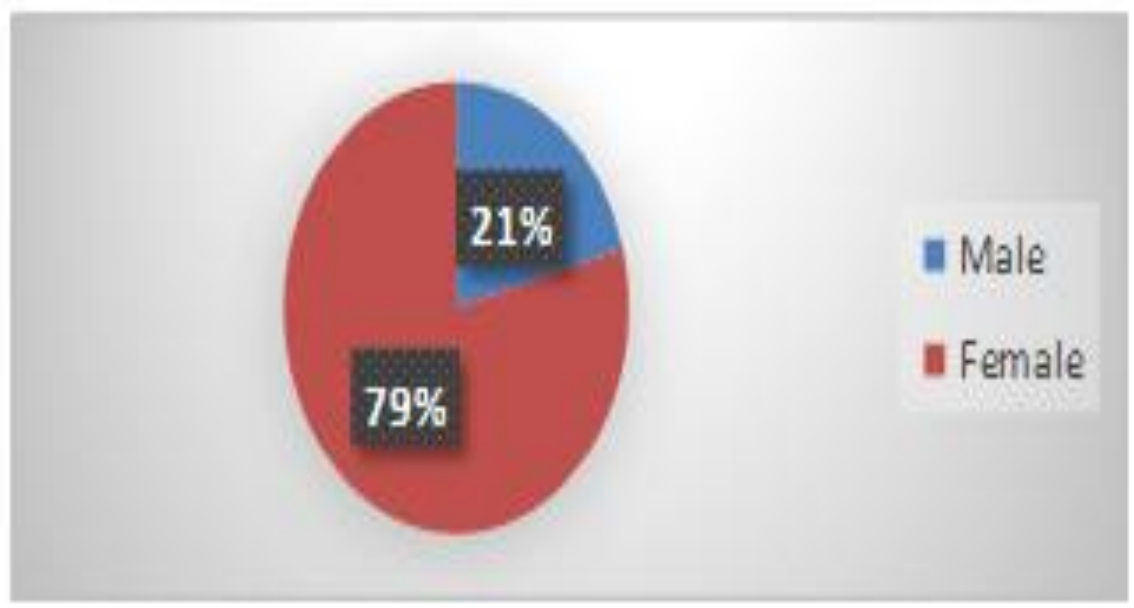

Figure-4. Findings for Gender.

\subsection{Findings for Orientation Stage}

This section presents findings to answer RQ1- How is Orientation portrayed in critical reading activities. The orientation is the initial stage where learners work as a team through (a) online engagement to (b) identify and (c) interpret reading texts.

(a) Online Engagement

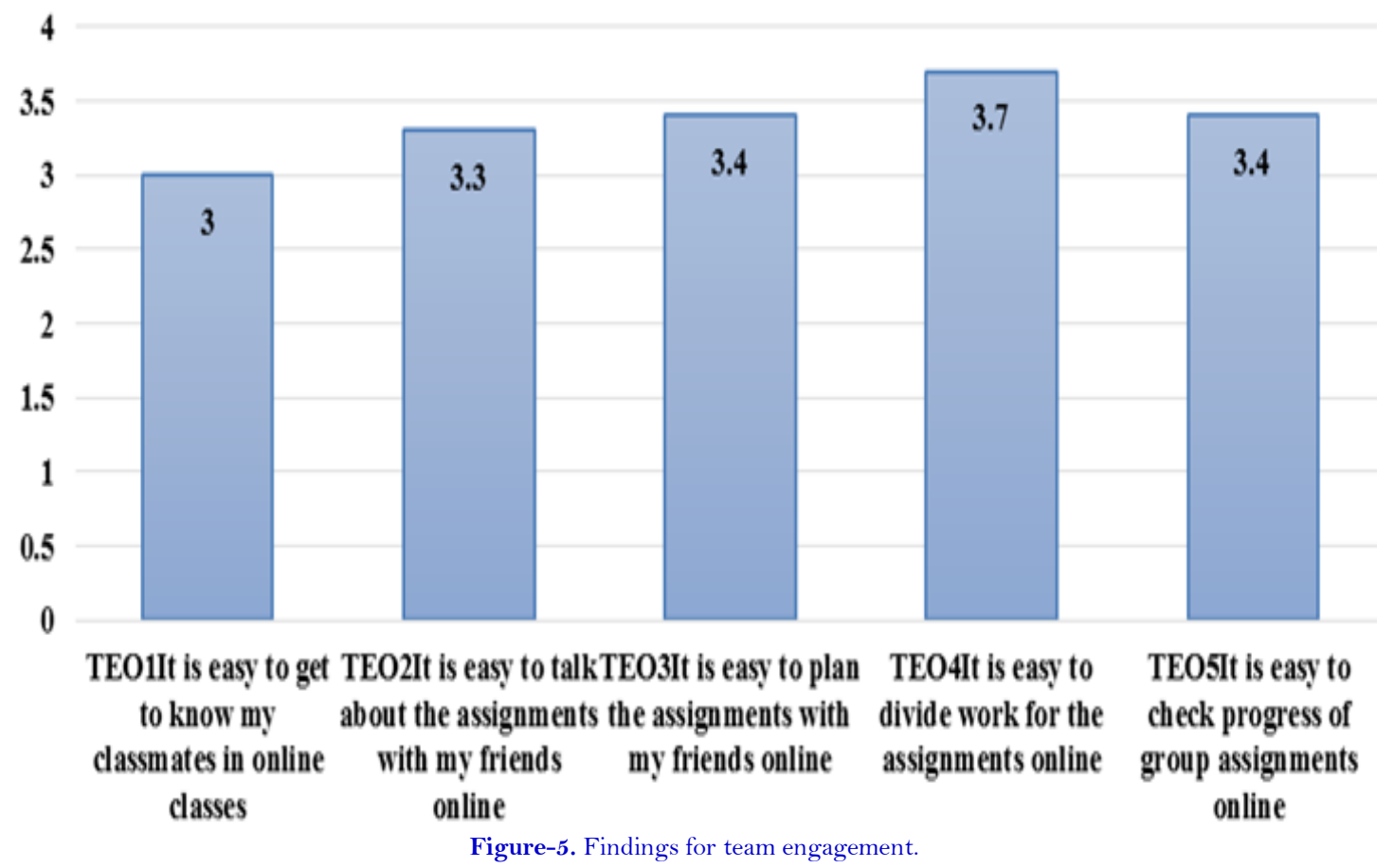

As displayed in Figure 5, in terms of team engagement, item TE04 has the highest mean score (3.7) which indicated that students find it easy to divide work for the assignments online. The second highest mean score is 3.4 which shows that students find it easy to plan the assignments with friends and to check progress of groups assignments online. Next, students find it easy to talk about the assignments with their finds online with a mean score of 3.3. Finally, the lowest mean score is 3.0 for the item it is easy to get to know my classmates in online classes'. 
(b) Identification Skills

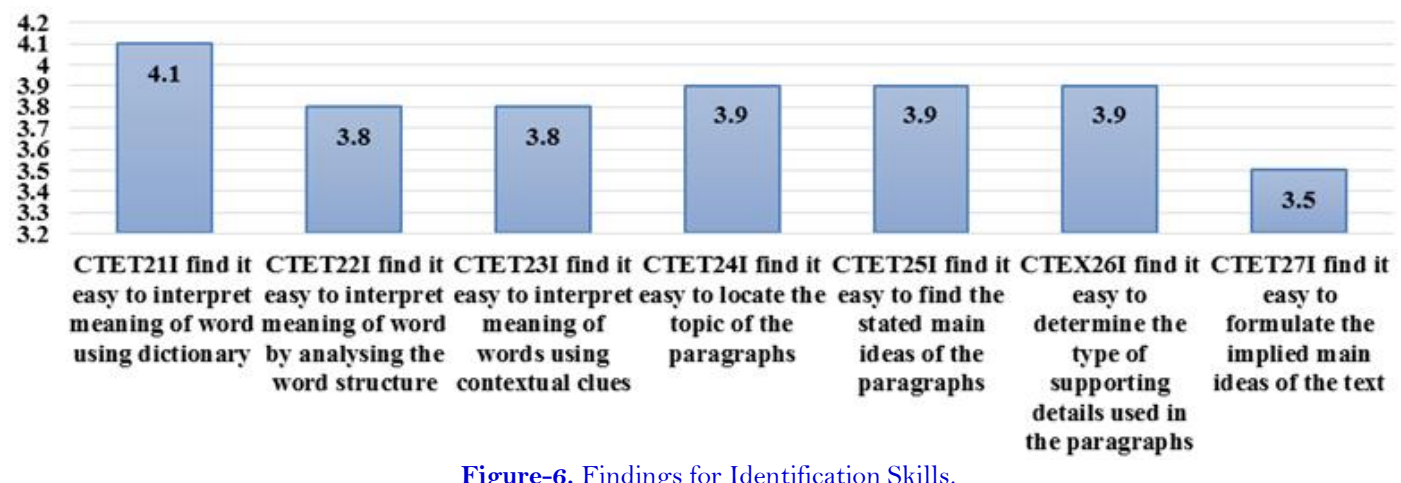

Figure-6. Findings for Identification Skills.

Figure 6 displays the mean scores for the items regarding the students' identification skills in exploring texts. The highest mean value is 4.1 , which shows that the students find it easy to interpret meaning of word using dictionary. The second highest mean score is 3.9. This means that the students also find it easy to locate the topic of the paragraphs, the stated main ideas of the paragraphs and could determine the types of supporting details used in the paragraphs easily. Next, the students agree that they can easily interpret meaning of word by analyzing word structure and using contextual clues, indicated by a mean score of 3.8. Finally, the item with the lowest score is 'find it easy to formulate the implied main ideas of the text', with a mean score of 3.5.

(c) Interpretation Skills

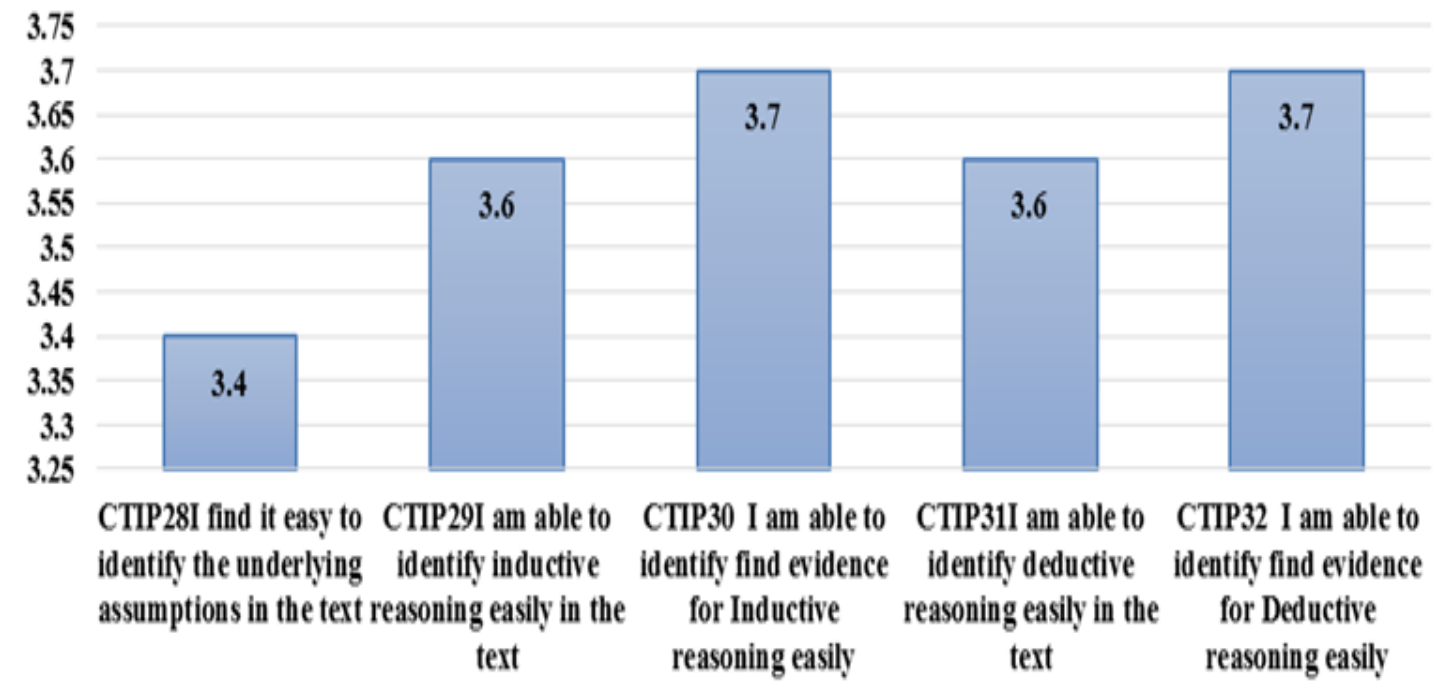

Figure-7. Findings for Interpretation Skills.

Figure 7 presents the mean scores for students' interpretation skills in identifying problems. The highest mean score is 3.7 which shows that the students are able to identify evidence for inductive and deductive reasoning easily. Next, the second highest mean score is 3.6 which shows the students find it easy to identify the inductive and deductive reasoning easily. Lastly, the lowest mean score is 3.4 as the students can identify the underlying assumptions in the text easily.

\subsection{Findings for Conflict Stage}

This section presents the answer to $\mathrm{RQ}^{2}$ - How do learners deal with Conflict during critical reading activities? Initial discussion (especially among newly formed team members) may face (a)conflicts. The conflicts actually pave way for the use of (b) analysis and also (c) inference and evaluation skills. 
(a) Conflicts

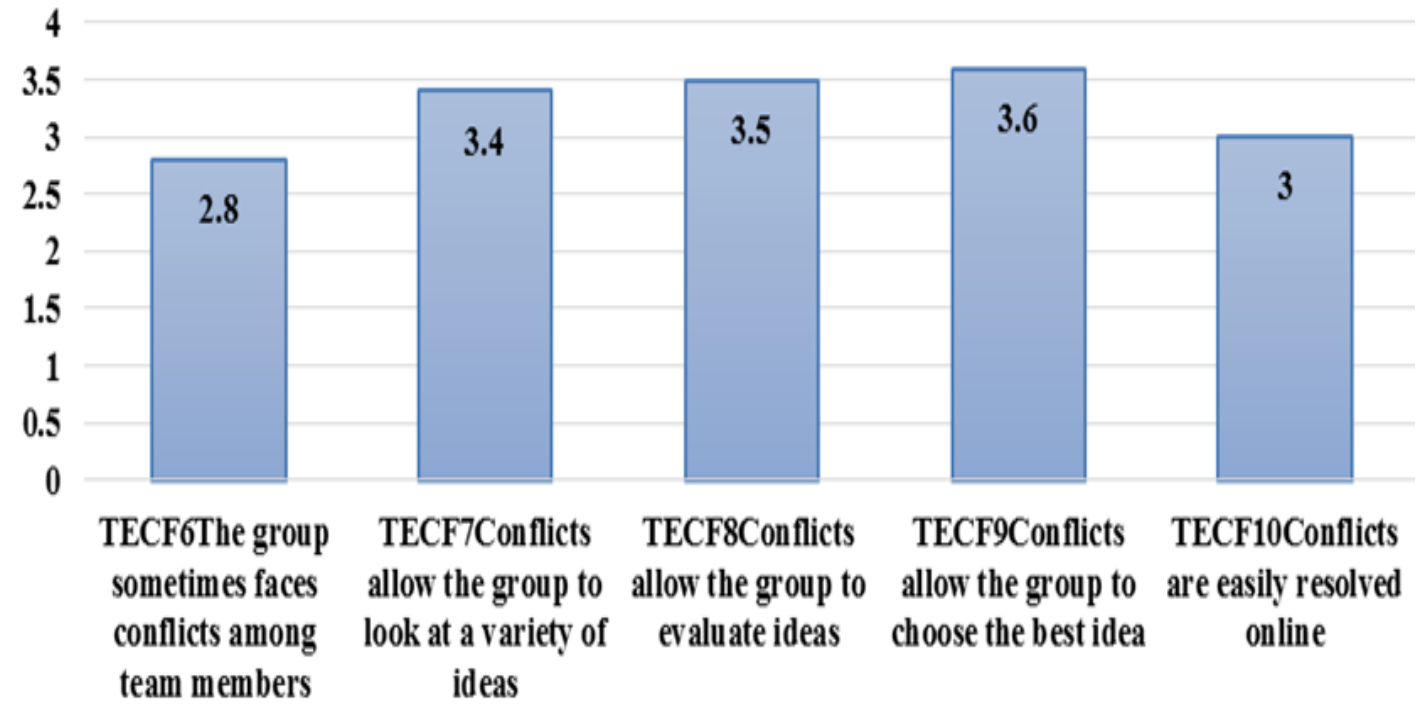

Figure-8. Findings for Conflict.

Based on Figure 8 above, the highest mean score for the learners' team engagement in dealing with conflict during critical reading activities. The highest mean score is 3.6 which means that the students agree that conflict allow the group to choose the best idea. Next, the second highest mean score is 3.5, as the students are in agreement that conflicts allow the group to evaluate ideas. Moreover, they also view conflicts enable the group to look at variety of ideas (mean score: 3.4). The students also feel that conflicts are easily resolved online, with a mean score of 3. Lastly, the lowest mean score is 2.8 , on their perceptions on the possibility of the group to find conflict among team members.

(b) Analysis Skill

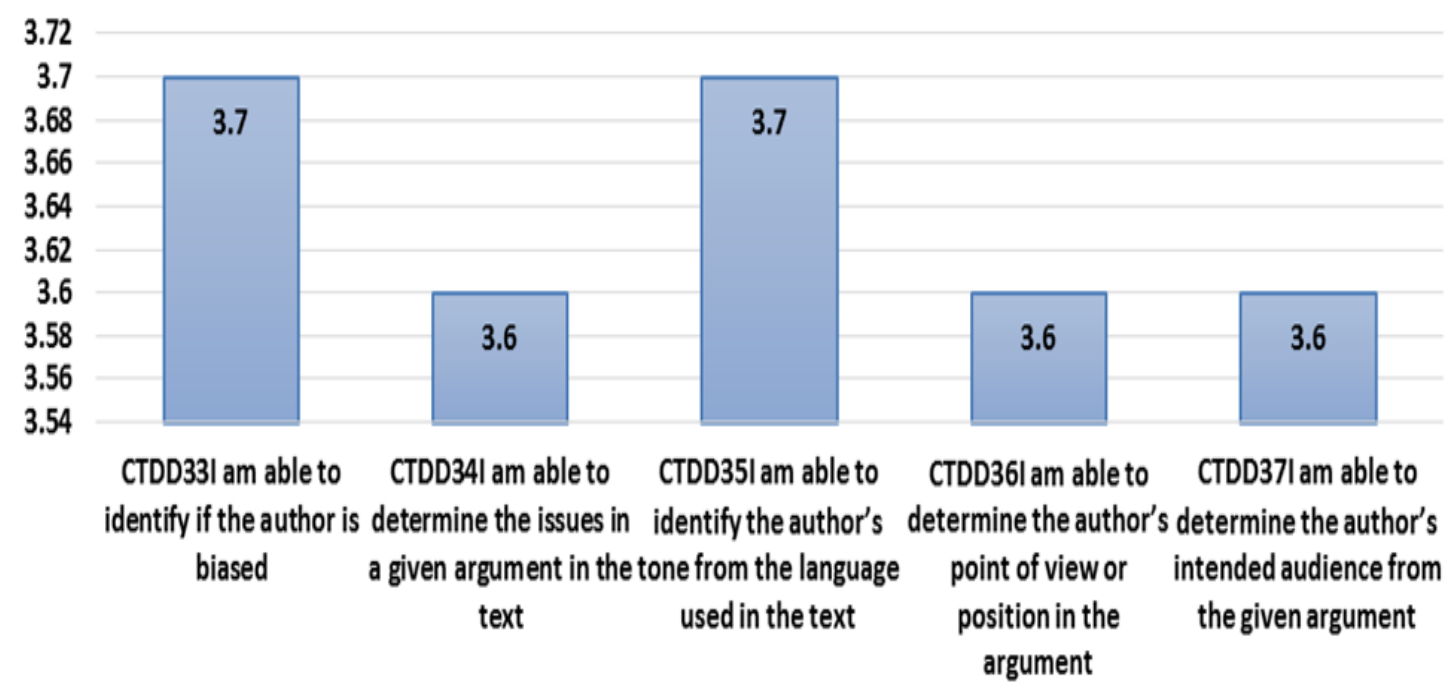

Figure-9. Findings for analysis skills.

Figure 9 portrays the findings for analysis skills in reading. Item CTDD33 and CTD35 have the highest mean score with 3.7. It indicates that the students perceived that they could almost identify when the author was biased, and they could also almost identify the author's tone from the language used in the text. The least mean score was 3.6 and it was shared by item CTDD34, CTDD36 and CTDD37. This means that the students highly likely could determine the issues, author's point of view and author's intended audience that were discussed from the argument in the text. Hence, it can be said that students were able to use their analysis skills in reading the text. 


\section{(c) Inference and Evaluation Skills}

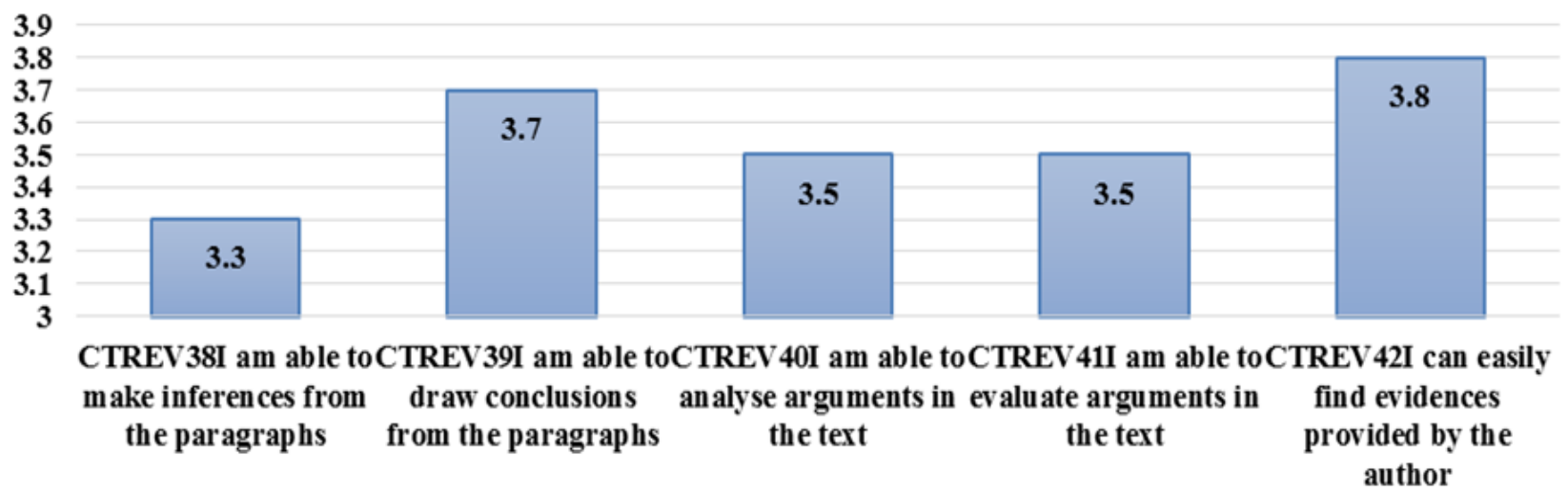

Figure-10. Findings for inference and evaluation skills.

Figure 10 depicts the findings for inference and evaluation skills in reading. The highest mean score is obtained by item CTREV42 with 3.8 where students may easily find evidence provided by the author followed by item CTRVE 39 with a mean score of 3.7. The students perceived that they could draw conclusions from the paragraphs in the text. Item CTREV 40 and 41 have the same mean score which is 3.5. This means that students observed that they could analyze and evaluate the arguments in the text. Last but not the least, item CTREV 38 obtained the least mean score which is 3.3. This indicates that students were quite unsure to make inferences from the paragraphs. Thus, it can be assumed that students could distinguish their ability in inferencing and evaluating the text while reading.

\subsection{Findings for Consensus Stage}

This section answers RQ 3- How do learners arrive at the Consensus during critical reading activities? Next, in order for the group to arrive at the (a) consensus, the members (especially the group leader) need use their (b) explanation skills.

(a) Consensus

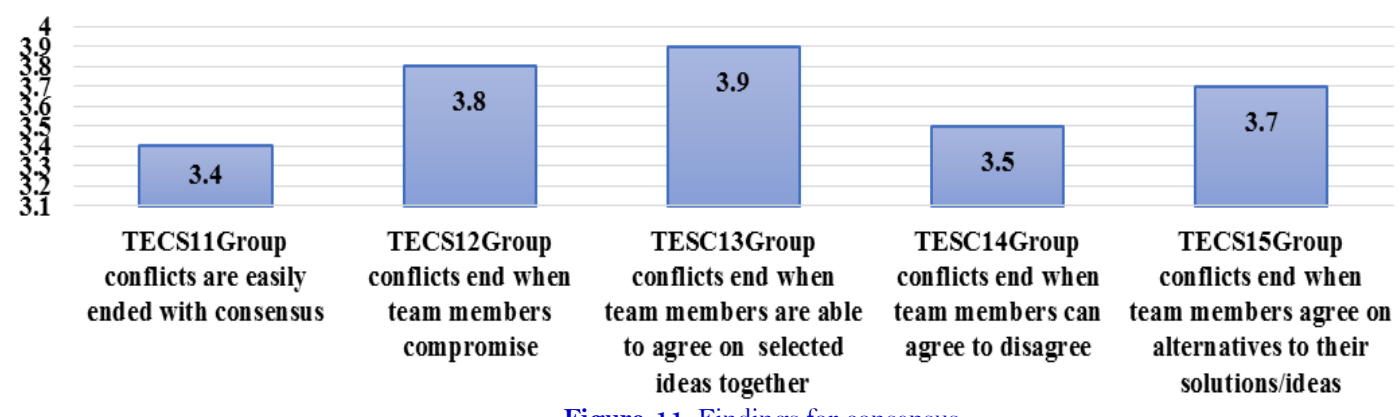

Figure-11. Findings for consensus.

Figure 11 presents the mean score for "Findings for Consensus". The highest mean score with 3.9 indicates group conflicts end when team members are able to agree on selected ideas together. The second highest mean score with 3.8 demonstrates group conflicts end when team members compromise. The third highest mean score with 3.7 represents group conflicts end when team members agree on alternatives to their solutions/ideas. The fourth mean score with 3.5 reflects group conflicts end when team members can agree to disagree and the fifth mean score with 3.4 implies group conflicts are easily ended with consensus. 
(b) Explanation Skills

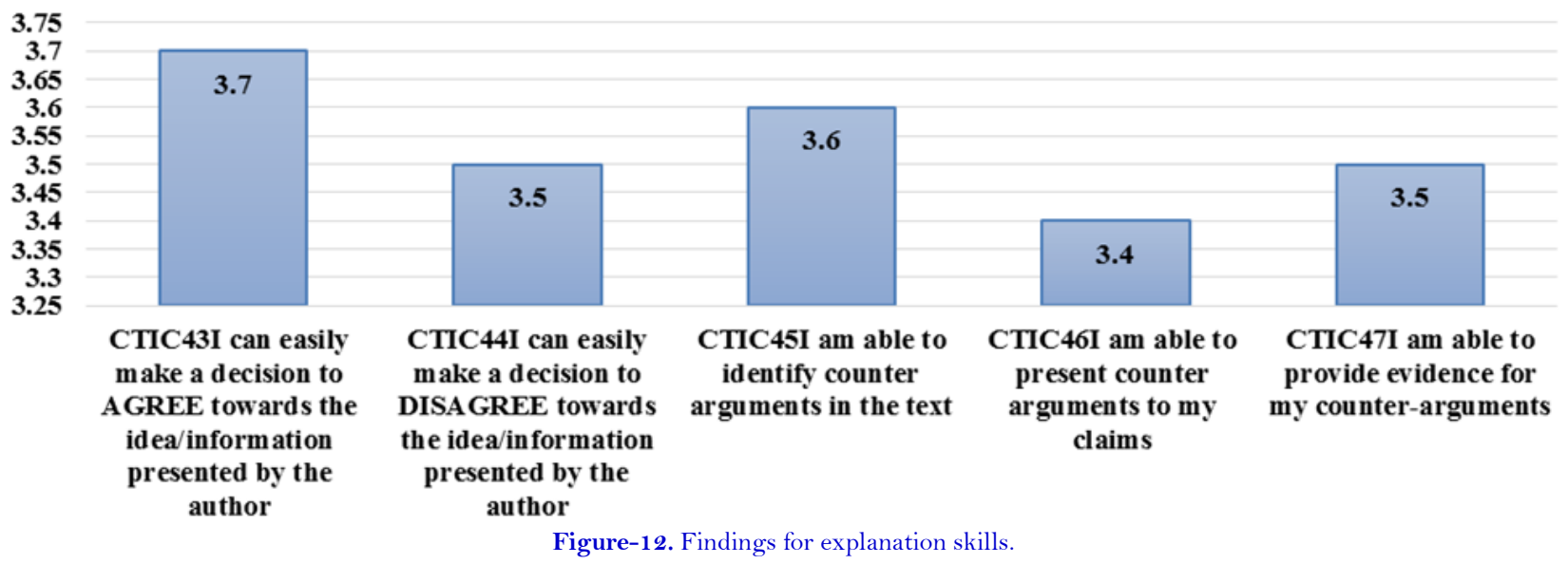

Research question 3 Figure 12 that asked "how do learners arrive at the Consensus during critical reading activities?” is to look into the explanation skills to improve learners' comprehension. There are five (5) items sought for the responses. The highest mean score (3.7) is for the item "can easily make a decision to AGREE towards the idea/information presented by the author". The element to agree and disagree is based on the readers' judgment and therefore, readers may fall into a decision to agree-disagree when they are very much influenced by the authors' explanation, elaboration, strong supporting evidences provided, and also the way the authors put forth their words in the writing. Hence, the participants saw that this element is easy to fulfil and comprehend as they read. The mean score for item "can easily make a decision to DISAGREE towards the idea/information presented by the author" is 3.5 which a slight low than the above item asked about 'a decision to AGREE'. Next item is "am able to identify counter arguments in the text”. The mean score is 3.6. To counter argument requires skillful thoughts of the readers. The mean score is the second highest is to indicate that the participants are good at their reading skills and they are deemed critical during the reading process. The next mean score is 3.5 for "am able to provide evidence for my counter-arguments" which is equivalent to item 'decision to agree'. This is less popular as to provide evidence requires one to put extra effort seeking for the strength and weakness of points from the reading. This task is tedious that not all readers are in favor to fulfil. The lowest mean (3.4) is for the item "am able to present counter arguments to my claims". This item is not a favorite skill that this element is one of the highest order reading skills. Not only those readers need to find supports or evidences from the reading, they also have to reason out their stands. Not all readers are ready when it reaches to this critical stage in their reading activities.

\subsection{Findings for Closure}

This section presents the answers to RQ4- How is closure done during critical reading activities? Finally, the (a) closure is done as the group makes reflections that can act as (b) self-regulation.

As can be seen in Figure 13, the highest mean score for students' closure is item TECL20 (4.0) which shows that team members work together to make changes before the final work. For item TECL19 'Team members take responsibility to make improvements', the mean score is slightly lower which is 3.9. Next, students agree that team members take responsibility to make improvements before the closure which is indicated by the mean score of 3.8. The students also find it easy for group members to support the decision of the leader with a mean score of 3.7. Lastly, the lowest mean score is for the item TECL17 'It is easy to arrive at the closure of the group decision' which is 3.6 . 


\section{(a) Closure}

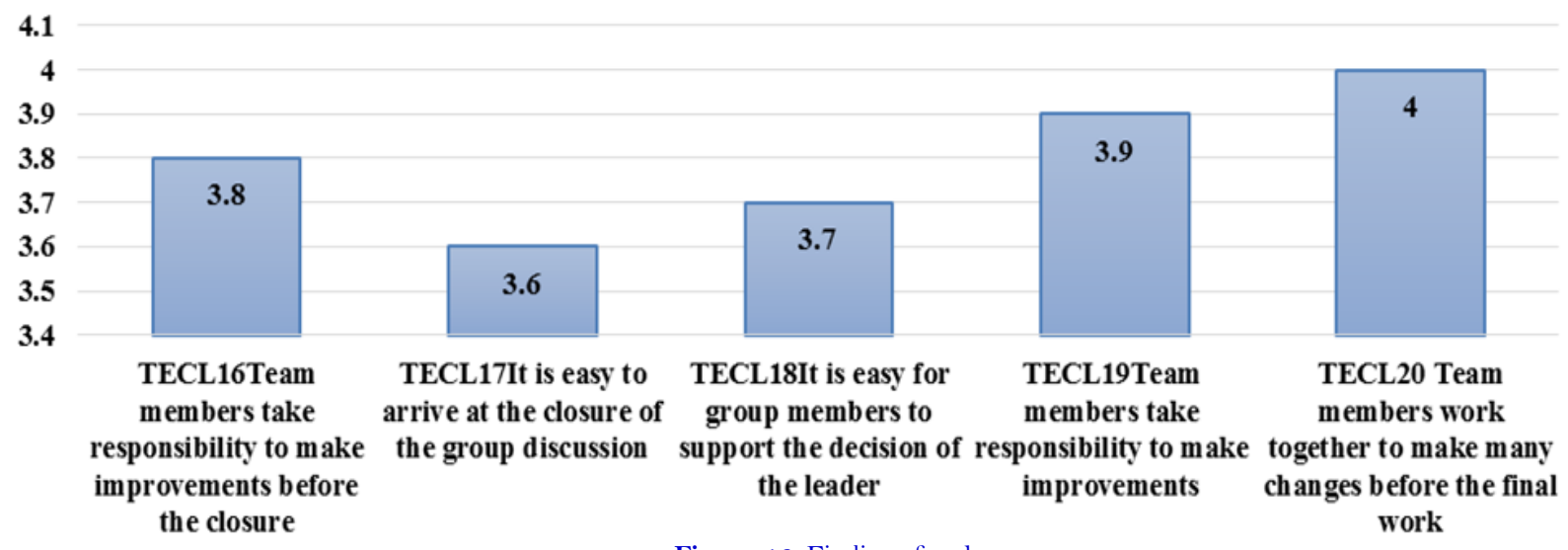

Figure-13. Findings for closure.

(b) Self-Regulation Skills

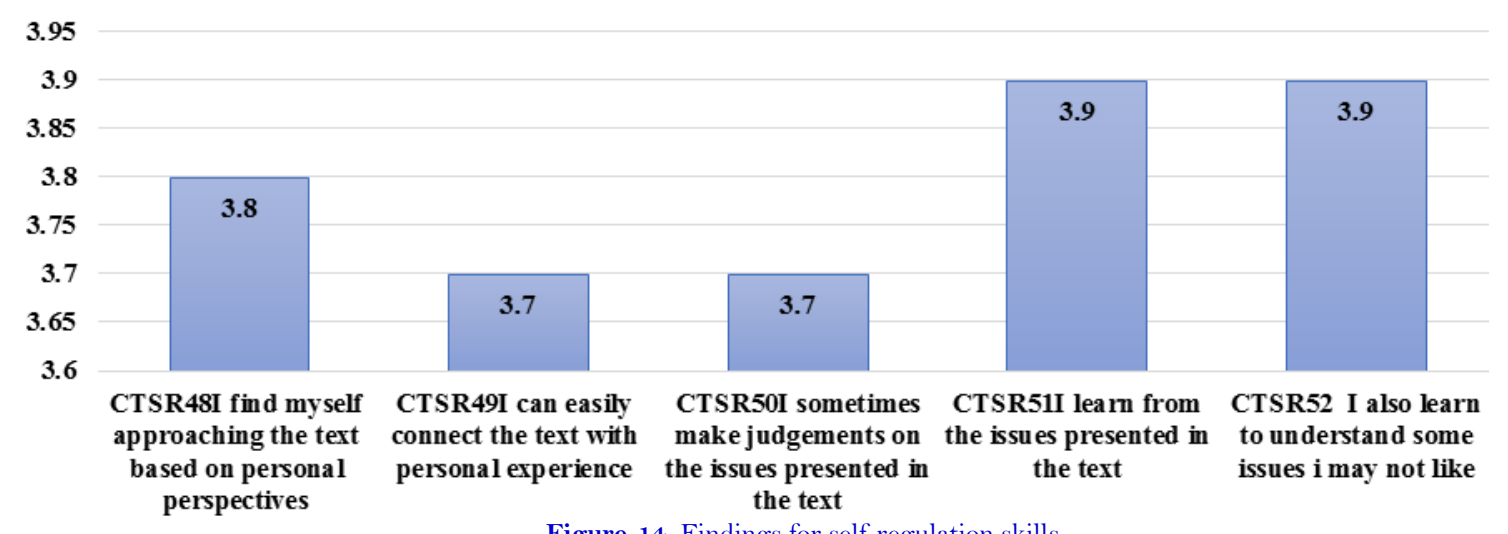

Figure-14. Findings for self-regulation skills.

Based on Figure 14, the highest mean value is 3.9, which shows that the students agree that they learn from the issues presented in the text and that they learn to understand some issues that they dislike. Next, the second highest mean score is 3.8 as the students find themselves approaching the text based on personal perspectives. Lastly, the students also feel that they can easily connect the text with personal experience and sometimes make judgement on the issues presented in the text, indicated by a mean score of 3.7.

\section{CONCLUSION}

\subsection{Summary of Findings}

Based on the findings obtained, students indicated that they would work better in dividing the work via online. This finding is in line with research done by Situmorang (2021) where students portrayed positive attitudes toward group work, and they perceived it as advantageous. Other than that, students implied that they could interpret meaning with the help of a dictionary well and at the same time, they could locate the topic, stated main ideas and types of supporting details in paragraphs. They could also identify the evidence for inductive and deductive reasonings. These findings were supported with research done by Suacillo et al. (2016) where they discovered that students would illustrate better comprehension of a text when they used suitable critical reading strategies.

Moreover, the students can also easily find evidence provided by the author in applying their inference and evaluation skills. This is due to the meaningful learning experienced by the students when they learnt as a whole group (Koçak, 2018). Furthermore, the students revealed that the conflicts ended when all team members agreed with the selected ideas, and they will work together if they need to change any content in their assignment. They would also ensure that all team members took responsibility to make improvements. The findings suggested that 
they would learn the issues from the text and even issues that they may not like. Based on these findings, it can be said that the findings are parallel with research done by Wilson (2016). He mentioned that the students would interact better when they were involved in reading activities, especially group work activities.

\subsection{Pedagogical Implications}

In conclusion, Tubb’s Group Engagement Theory needs to be implemented for a successful collaborative learning in Critical Reading class. The four stages in Tubb's Group Engagement Theory, which are called Orientation, Conflict, Consensus and Closure support the efficiency of learning Critical Reading. Firstly, the students will get to know each other and accept their differences in the Orientation Stage. Then, they will discuss the tasks and offer solutions for the given tasks based on their own perspectives in the Conflict stage. This will minimize learning anxiety optimally and promise an enjoyable learning experience to the students. Subsequently, the students will resolve the answer for the tasks in the Consensus stage and that will finally lead to the Closure stage where everyone in the group reaches the final decision in finalizing the given task. As stated by Masiran, Ibrahim, Awang, and Lim (2020); Kontowski (2020) that learners from multicultural backgrounds with different behavioral and emotional problems will produce better work in the classroom, if instructors conduct all the stages efficiently.

\subsection{Suggestions for Future Research}

Future researchers could explore the conversations during group interaction to analyze what was said at each stage of Tubbs Model. Analysis could also be on the effect of the group conflicts on the quality of group work.

Funding: This study received no specific financial support.

Competing Interests: The authors declare that they have no competing interests.

Acknowledgement: All authors contributed equally to the conception and design of the study

\section{REFERENCES}

Amritesh, P., \& Jeayaram, S. (2019). A study on learning environment, palakkad. International Journal of Recent Technology and Engineering, 7(6), 1019-1025.

Bandura, A. (1977). Social learning theory. Englewood Cliffs, NJ: Prentice Hall.

Barashid, M. (2020). Investigating the critical reading skills for Saudi EFL learners through graphic organizers instructional program. $\quad$ Retrieved from https://www.researchgate.net/publication/346243805_Investigating_the_Critical_Reading_Skills_for_Saudi_EFL_L earners_through_Graphic_Organizers_Instructional_Program.

Begunova, M. (2018). Critical reading strategies in teaching university students in non-linguistic environment. Web of Scholar, $4(2), 73-77$.

Blooms. (1956). Taxonomy of educational objectives. The classification of educational goals. London: Longmans, Green and Co Ltd.

Borůvková, R., \& Emanovský, P. (2016). Small group learning methods and their effect on learners' relationships. Problems of Education in the 21st Century, 7O(1), 45-58. Available at: https://doi.org/10.33225/pec/16.70.45.

Browne, M. N., \& Keeley, S. M. (2007). Asking the right questions: A guide to critical thinking. New Jersey: Pearson Prentice Hall.

Burke, A. (2011). Group work: How to use groups effectively. Journal of Effective Teaching, 11(2), 87-95.

Carillo, E. C. (2017). How students read: Some thoughts on why this matters. English Journal, 106(5), 34-39.

De Souza, T. (2017). The effect of Florida assessments for instruction in reading programs on Florida standards assessments test scores. Doctoral Dissertation, Northcentral University.

Diaz, D. (2018). Improving literacy in adult ELLs through metacognitive strategies for reading comprehension and academic achievement Doctoral Dissertation, Northcentral University. 
Egan, E. M. (2014). Interventions for English language learners: Effects of reading recovery on reading achievement: Northeastern University, Boston, Massachusetts (Order No.3681313). Available from ProQuest Dissertations \& Theses Global. (1655594725). https://doi.org/10.17760/d20128386 from http://search.proquest.com.ezaccess.library.uitm.edu.my/dissertations-theses/interventions-english-languagelearners-effects/docview/1655594725/se-2? accountid=42518.

Howard, P. J., Gorzycki, M., Desa, G., \& Allen, D. D. (2018). Academic reading: Comparing students' and faculty perceptions of its value, practice, and pedagogy. Journal of College Reading and Learning, 48(3), 189-209. Available at: https://doi.org/10.1080/10790195.2018.1472942.

Javadi, Y., \& Tahmasbi, M. (2020). Application of humanism teaching theory and humanistic approach to education in course. Theory and Practice in Language Studies, 1O(1), 40-48. Available at: https://doi.org/10.17507/tpls.1001.06.

Jayendran, N., Ramanathan, A., \& Nagpal, S. (2021). Language acquisition and language learning. In Language Education (pp. 59-80). India: Routledge.

Karanja, W. A. N. J. I. K. U. (2015). Effects of reading difficulties on academic performance among form three students in public secondary schools, Kiambu County, Kenya. Unpublished MED Thesis, Kenyatta University.

Khabiri, M., \& Pakzad, M. (2012). The effect of teaching critical reading strategies on EFL learners' vocabulary retention. Journal of Teaching Language Skills, 31(1), 73-106.

Koçak, M. (2018). An effective method of acquiring efficient-critical reading skills for students: Reading group activity. Paper presented at the IASL Annual Conference Proceedings.

Kontowski, D. (2020). European liberal education 1990-2015: A critical exploration of commonality in the visions of eight first leaders. PhD Thesis, University of Winchester.

Koray, Ö., \& Çetinkılıç, S. (2020). The use of critical reading in understanding scientific texts on academic performance and problem-solving skills. Science Education International, 31(4), 400-409. Available at: https://doi.org/10.33828/sei.v31.i4.9.

Krish, P., Hussin, S., \& Sivapuniam, N. (2011). Language learning and language acquisition in online forums. 3L: Language, Linguistics, Literature. The Southeast Asian Journal of Engl: sh Language Studies, 17(2), 91-100.

Larking, M. (2017). Critical reading strategies in the advanced English classroom. English Teaching, 2(4), 50-65.

Malakowsky, D. J. (2018). Modified extensive reading intervention on title 1 Michigan English learners' fluency using non-curriculum based measurement. Doctoral Dissertation, Northcentral University.

Masiran, R., Ibrahim, N., Awang, H., \& Lim, P. Y. (2020). Improving multicultural parenting program for children with emotional and behavioral problems: An integrated review. Asian Journal of Psychiatry, 51, 101851. Available at: https://doi.org/10.1016/j.ajp.2019.101851.

Mullis, I. V., Martin, M. O., Foy, P., \& Hooper, M. (2017). ePIRLS 2016: International results in online informational reading: International Association for the Evaluation of Educational Achievement. MA: TIMSS \& PIRLS International Study Center. Retrieved from http://timssandpirls.bc.edu/pirls2016/international-results/wpcontent/uploads/structure/CompletePDF/P16-ePIRLS-International-Results-in-Online-Informational-Reading.pdf.

Pearson, J., Owen, T., Thimbleby, H., \& Buchanan, G. R. (2012). Co-reading. Paper presented at the Proceedings of the 12th ACM/IEEE-CS Joint Conference on Digital Libraries - JCDL' 12.

Piaget, J. (2001). The psychology of intelligence (Routledge Classics) (1st ed., Vol. 92). London New York: Routledge.

Pradnyadewi, D. A. M., \& Kristiani, P. E. (2021). The use of quizizz in improving students' reading skill. The Art of Teaching English as a Foreign Language, 1(2), 1-7. Available at: https://doi.org/10.36663/tatefl.v 1i2.93.

Rezaei, A. R. (2018). Effective groupwork strategies: Faculty and students' perspectives. Journal of Education and Learning, 7(5), 1-10. Available at: https://doi.org/10.5539/jel.v7n5p1.

Sand, D. (2016). An examination of postsecondary faculty and the extent of critical reading taught in 100-level introductory biology and American history courses in publicly funded two-year and four-year Pennsylvania institutions. Doctoral Dissertation, Holy Family University. 
Situmorang, M. A. (2021). Students' perception of using group work in English class. Journal of English teaching, 7(1), 81-88. Available at: https://doi.org/10.33541/jet.v7i1.2302.

Stajkovic, A., \& Sergent, K. S. (2019). Social cognitive theory. Retrieved from https://www.researchgate.net/publication/335454302_Social_Cognitive_Theory.

Suacillo, C. I. M., Um, S., Velasquez, J., Villaflores, H., \& Cequena, M. (2016). Critical reading strategies, reading comprehension and writing performance of ESL college students: A correlational study. International Journal of Advanced Research, 4(9), 610-623. Available at: https://doi.org/10.21474/ijaro1/1526.

Sultan, A. R., \& Nurhadi, E. T. P. (2017). The development of a critical reading learning model to promote university students' critical awareness. The New Educational Review, 48(2), 76-86. Available at: https://doi.org/10.15804/tner.2017.48.2.06.

Sundari, H. (2017). Classroom interaction in teaching English as foreign language at lower secondary schools in Indonesia. Advances in Language and Literary Studies, 8(6), 147-154. Available at: https://doi.org/10.7575/aiac.alls.v.8n.6p.147.

Thorndike, E. L. (2017). Educational psychology (2nd ed.). Enlarged: Leopold Classic Library.

Tubbs, S. L. (1994). Team leadership: A systems approach. Journal of Leadership Studies, 1(2), 27-45. Available at: https://doi.org/10.1177/107179199400100204.

Vilches, M. (2020). Increasing social integration for ELLS. Education and Human Development Master's Theses. 1273.

Vygotsky, L. S. (1978). Mind in society: The development of higher psychological processes. Cambridge, MA: Harvard University Press.

Vygotsky, L. S. (1987). Thinking and speech. In R.W. Rieber \& A.S. Carton (Eds.), The collected works of L.S. Vygotsky: Problems of general psychology (Vol. 1, pp. 239-285). New York: Plenum Press.

Wilson, K. (2016). Critical reading, critical thinking: Delicate scaffolding in English for academic purposes (EAP). Thinking Skills and Creativity, 22, 256-265. Available at: https://doi.org/10.1016/j.tsc.2016.10.002.

Yu, J. (2015). Analysis of critical reading strategies and its effect on college English reading. Theory and Practice in Language Studies, 5(1), 134-138. Available at: http://doi.org/10.17507/tpls.0501.18.

Views and opinions expressed in this article are the views and opinions of the author(s), International Journal of Asian Social Science shall not be responsible or answerable for any loss, damage or liability etc. caused in relation to/arising out of the use of the content. 